\title{
NEW SPECIES OF GEODEPHAGOUS COLEOPTERA FROM NEW ZEALAND.
}

BY H. W. BATES, F.L.S.

In the paper on the Geodephagous Coleoptera of New Zealand, which I published in 1874, eighty-nine species were catalogued as belonging to the islands. To this number must be added three species described by Captain Broun in the Trans. of the New Zealand Institute, nine species by myself in Entom. Monthly Mag., Jan. and Feb, 1878 (Vol. xiv, pp. 191-196), and eighteen in the following pages, making, in all, one hundred and nineteen species now known as belonging to the New Zealand Fauna in this department.

\section{Cicindela austromontana, $n . s p$.}

Oblonga, supra saturate olivacea, opaca, subtilissime sculpturata, fere lavis; elytris lunula humerali, fasciaque brevi mediana vix curvata, per marginem cum lunula apicali connexa, albis: labro valde transverso, margine antico fere recto, medio tridentato; capite subtilissime strigoso; thorace lateribus rotundato, postice magis quam antice angustato: elytris apice rotundatis, suturâ spinosa, dorso aqualiter subtilissime granulatis : corpore subtus femoribusque aneis, sparsim albopilosis.

Long. 5 lin., ơ .

Closely allied to $C$. Feredayi, from which it may be distinguished by the form of the anterior edge of the labrum. This, in the $\delta$ of C. Feredayi, is angularly produced in the middle, and ends in a stout tooth; but in the same sex of $C$. austromontana, it is not produced, forming in the middle a sharp tooth with a more obtuse one on each side. Besides this definite structural character, the new species differs in being more parallel-sided, duller in colour, and in the sculpture of the elytra consisting of granules instead of punctures. The usual row of large green punctures is not visible. The white markings are not very different; but the white margin is interrupted at the end of the humeral lunule, and the median belt is not bent and prolonged posteriorly. The forehead and thorax have a few long white hairs.

Castle Hill, Eastern slope of New Zealand Alps, Canterbury (C. M. Wakefield); two examples.

\section{Physolesthus insularis.}

Oblongus, subdepressus, piceo-niger, elytris thoraceque marginibus mufescentibus, capite thoraceque subopacis, illo antice late concavo; thorace transversim quadrato postice modice angustato, angulis obtusis, ibique margine elevato, margine postico late rotundato; elytris politis, striatis, interstitiis convexis.

Long. $2 \frac{1}{4}$ lin.

Considerably smalier than either of the Australian species already described of this genus; but agreeing in almost every other respect 
with Ph. australis (Chaudoir). It bears a strong resemblance to the European Badister peltatus, from which its swollen labial palpi at once distinguish it. It is smaller, and has a shorter thorax, the hind angles having a broad smooth fovea, from which springs a strong bristle. The pale margin of the elytra is confined to the reflexed rim.

Canterbury Province (C. M. Wakefield).

\section{LeCANOMERUS OBESULUS.}

Oblongo-ovatus, convexus, subœneo-niger, nitidus, antennis basi, palpis, tibiis (apice piceo excepto) tarsisque apice rufotestaceis; marginibus inflectis thoracis et elytrorum plus minusve rufescentibus; thorace transversim quadrato, lateribus rotundatis, angulis posticis fere nullis, foveis basalibus sparsim grosse punctatis; elytris striatis, interstitiis paulo convexis, apice leviter sinuatis.

ठ. Tarsis quatuor anticis, articulis 2--3 latissime dilatatis, $2^{\text {do }}$ fere semicirculari, 3io brevi.

Long. $2 \frac{1}{4}-2 \frac{1}{2}, \delta$ \& .

Distinguished from the other species of the genus by its greater convexity and the sharper and deeper striation of the elytra. The colour of the upper surface is shining black, with a faint brassy metallic sheen on the elytra. The extreme lateral margins of the thorax and the elytra are rufescent; the two basal joints of the antennæ, the palpi and the basal half of the tibiæ are also of the same colour. The basal foveæ of the thorax are coarsely but sparsely punctured.

West Coast, S. Island, numerous examples (C. M. Wakefield).

\section{Hrpharpax abstrusus.}

H. antarctico proxime affinis, dimidio major. Oblongus, aneo.niger, antennarum articulo $1^{\text {nio }}$, tibiisque (apicibus exceptis) rufotestaceis: thorace transversim quadrato, postice paulo magis quam antice angustato, lateribus antice late rotundatis, angulis posticis paulo obtusis apice rotundatis, foveis basalibus sparsim grosse punctatis: elytris apice oblique fortiter sinuatis, apud suturam productis, suprà undulatis, sericeo-nitentibus (pracipiue \&), striatis, interstitio tertio apicem versùs puncto majori conspicuo.

Long. 3 lin., $\delta$ ㅇ․

Agrees with $H$. antarcticus in almost everything except size; Castelnau giving $2 \frac{1}{2}$ lines as the length of that species, which agrees with a very large number of specimens that I have examined. "The feeble punctiform impression behind " of Castelnau's phrase also indicates a difference between antarcticus and the present species, in which the interstitial puncture is very large and conspicuous. When the two species are compared, several other points of difference are observable, which it is impossible to render clear by description. 
Described from a single pair ( $\sigma q$ ) from Auckland.

A specimen in Mr. Wakefield's collection, ticketed "Tairua, Capt. Broun," and others which I have examined from "Wellington," and from parts of New Zealand not specified, differ from the type described in the sutural apex of the elytra not being notably prolonged, and in the thorax being much less rounded on the sides anteriorly and more gradually narrowed to the base. Some of the specimens have a slight greenish tinge, and others have two basal joints of the antennæ clearish red. It is impossible, without much further material, to decide whether we have here to deal with several closely allied species, or only with a single variable one.

\section{Bembidium orbiferum.}

Oblongo-ovatum, convexum, nigro-aneum, palpis, antennarum articulis basalibus pedibusque fulvo-testaceis: capite ovato, oculis modice convexis, sulcis frontalibus latis: thorace fere globoso, late rotundato, juxta basin constricto, ibique lateribus parallelis, angulis rectis: elytris apice angustatis, striato-punctatis, interstitiis vix convexis, tertio punctis duobis parvis; striis exterioribus apice vix impressis.

\section{Long. $2 \frac{1}{2}-3$ lin. of 9 .}

§. Tarsi antici, articulis duobus dilatatis apice intus productis, primo oblongo, secundo parvo.

Allied to $B$. rotundicolle, callipeplum, \&c. Thorax much more strongly rounded, more constricted at the base, with hind angles more distinctly rectangular. It is also larger than the allied species, more convex and broader, the thorax being also larger in proportion to the whole insect. The colour of the upper surface is dark brassy, more or less cyaneous. The thoracic foveæ, as in the rest of this small group, are feebly marked; long, narrow, and situated close to the hind margin near the angle. The elytra taper strongly just before the apex, and are there more or less testaceous. The striæ are but feebly impressed, but the punctures are strong. The third interstice has only two small punctures. The first dilated joint of the male tarsi is much longer than in the allied species.

West Coast of Southern Island (C. M. Wakefield). I have also a specimen from Mr. H. Edwards, ticketed "Auckland."

\section{Bembidium CHALCEIPES.}

B. anchonodero affine, at paullo latius, modice convexum, cuprascenti-ceneum : thorace fortiter rotundato, juxta basin fortiter angustato; elytris punctato-striatis, striis paullulum impressis, interstitiis planis; antennis articulo primo piceo; pedibus aneis.

Long. $2 \frac{1}{4}$ lin.

Closely allied to $B$. anchonoderum (Bates), having the same general proportions, $i$. e., the thorax is not so short relatively to the elytra 
as in B. parviceps and Tairuense, and not so broadly-rounded, and relatively large, as in $B$. eustictum and orbiferum. The insect is also broader and flatter. In nearly all the specimens, the colour is dullish coppery-brown, with the head more greenish-brassy, and the antennæ and legs metallic, except the basal joint of the antennæ, and sometimes the tibiæ, which are more or less reddish-pitchy. The thorax is slightly shagreened, and, as usual in this group, rather abruptly narrowed just before the base, where the sides, for a short distance, are straight and parallel. The striæ of the elytra are very slightly impressed, but the punctures are very distinct, and are not wholly obliterated near the apex.

Typical examples of $B$. anchonoderum are only $1 \frac{3}{4}$ lin. long.

West Coast, Southern Island (C. M. Wakefield).

\section{BEMBIDIUM HOKITIKENSE.}

B. anchonodero proxime affine; differt colore nigro, thorace paulo latiori, striisque 3-7 apice evanescentibus. Supra paulo convexum, nigrum, leviter aneotinctum ; palpis, antennis, pedibusque nigris : thorace latiori, valde rotundato, juxta basin constricto ibique lateribus rectis, supra vix ruguloso; elytris punctato-striatis, striis $3-7$ ante apicem desinentibus, interstitiis paulo convexis. Long. $1 \frac{1}{2}$ lin.

Another of the numerous ill-defined species closely allied to $B$. anchonoderum. The colour of the two specimens taken by Mr. Wakefield is dull brassy-black, quite different from the brighter brassy tinge of anchonoderum. But the chief distinction lies in the broader form of the thorax, which is a conspicuous differentiating character, when the two species are compared side by side; another good character is offered by the smooth apical area of the elytra.

West Coast, South Island (C. M. Wakefield).

\section{Pterostichus (Trichosternus) aucklandicus.}

Elongato-oblongus, thorace quàm elytris distincte angustiori; capite magno, antice (cum mandibulis) elongato: viridi-aneus, nitidus, elytris fusco-ceneis; palpis antennisque rufo-piceis, pedibus piceis: thoracis margine antico arcuato-emarginato, mox pone angulos anticos leviter rotundato-dilatato, deinde gradatim, ante a.gulos posticos citius, sinuatim angustato, angulis rectis; fovea utrinque curvata valde profunda : elytris elongato-ovatis, postice latioribus, suprà profunde aqualiter striatis, striis fundo punctulatis, interstitiis passim convexis, tertio 3 vel 4-, septimo pluri-punctatis.

Long. 9-11 lin., ơ ㅇ․

Variat colore saturate cupreo, ut in $\mathrm{Tr}$. Australasiæ, Guér.

Distinguishable from $T r$. Sylvius and allies at once by its quite different form, due to relative narrowness of the thorax, which is also longer, less rounded anteriorly, and more gradually narrowed to the base, its basal foveæ are also deeper and more curved or branched. 
The head is much larger, especially much longer in front of the eyes; the mandibles and palpi being also longer. The elytra offer fewer points of difference; the interstices, however, maintain their convexity to the apex. The antennæ and palpi are reddish, and the legs dark pitchy-red in all the examples I have seen.

One example, from Auckland, differs from the above description, in being of a dull purplish-copper hue, inclining to æneous on the head and thorax.

\section{Pterostichus (Trichosternus) temukensis.}

Niger, supra fusco-cupreus, lateribus interdum viridibus; palpis apice rufis: thorace transversim quadrato, postice vix sinuatim angustato, angulis posticis paulo prominentibus; elytris elongato-oblongis, punctato-striatis, interstitiis convexis, 3 io, $5^{\text {to }}$, et $7^{\text {mo }}$ paulo latioribus.

Long. $9 \frac{1}{2}$ lin.

Very closely allied to Tr. Sylvius, and probably only a local form of the same. Comparing half-a-dozen specimens of each species, $T r$. temukensis, besides its more uniform and dusky-cupreous colour, appears rather more elongate and parallel-sided, and shows, in some examples, a conspicuous inequality in the width of the elytral interstices. But the most important and constant structural feature is in the curvature of the sides of the thorax; this, instead of forming a rather deep sinuation posteriorly between the middle and the tip of the hind angles, continues nearly to the base, as in Tr. antarcticus, the angle being somewhat abruptly, and, to a less degree than in Tr. Sylvius, turned outwards. The head and front margin of the thorax are formed the same in both species.

Temuka (C. M. Wakefield).

\section{Pterostichus (Trichosternus) Sylvius.}

Suprà viridi-ceneus vel cupreo-aneus, marginibus viridibus, nitidus, palpis apice rufis: thorace transversim quadrato, postice sinuatim angustato, angulis posticis prominentibus, acutis : elytris oblongis, punctato-striatis, interstitiis convexis, aqualibus, tertio 3 vel 4-, septimo pluri-punctato.

Long. 9 lin.

Agrees with the description of Feronia (Tr.) rectangula (Chaud.) in every important respect, except in the hind angles of the thorax, which, instead of being " exacte rectis," are decidedly projecting. This character is constant in the six examples before me, and is corroborated by the shining metallic colour of the whole upper surface, head included; Chaudoir giving as a speciality of $T r$. rectangula, "color paginæ superioris minus nitidus, elytrorum dorso fere nigricante." Specimens agreeing with this description were taken by Mr. Wakefield, at Rangiroa, whereas all his examples of $T r$. Sylvius came from Peel Forest. 
Tr. Sylvius has the head of moderate size in both sexes, with prominent eyes, and very small, rapidly narrowed, posterior orbits. The thorax is arcuate-emarginate on the fore margin, with rounded anterior angles, quite as broad at the base as at the apex, and moderately dilate-rotundate at a short distance behind the anterior angles. The elytra are dentate at the humeral angles, the punctures in the striæ are small and distinct, and the interstices become flatter towards the apex.

Peel Forest, S. Island (C. M. Wakefield).

\section{Pterostichus (Holcaspis) integratus.}

Elongatus, niger, suprà cuprescens; thorace quadrato, mox ante basin fortiter angustato, angulis acutis : elytris oblongo-ovatis, elongatis, striis vix punctulatis, omnino integris, septima apicem versus fortius impressa. Long. 9 lin., ơ + .

Very closely allied to Pt. vagepunctatus (White); differing chiefly in the striæ not being interrupted, and in the 7 th stria being deepened into a flexuous sulcus, extending from two-thirds its length to the apex. The elytra are rather more narrowed to the base, and consequently more oval than in Pt. vagepunctatus, and the hind femora of the $\delta$ are not dilated on their under surface.

Hokitika and Lake Paroa (C. M. Wakefield).

Pterostichus (Rhytisternus) puęla, Chaud., Bull. Mose., 1865, No. 3, p. 44 .

Captain Broun has recently sent examples of this Australian species from Tairua, both to Mr. Wakefield and Dr. Sharp, which bear the closest resemblance to specimens, with which I have compared them, from Queensland.

\section{Anchomenus (Platinus) otagoensis.}

Elongatus, deplanatus, nigro-piceus, opacus; antennis, palpis, pedibusque omnino melleo-fulvis : labro late emarginato; collo haud sulcato : thorace elongato-quadrato, postice longe, sinuatim sed modice angustato, angulis posticis subacutis; suprà impunctato, utrinque linea curvata paulo impressa a basifere ad marginem anticum ducta : elytris planis, elongato-ovatis, prope apicem fortiter sinuatis, apice suturali obtuso, subtruncatis; suprà subtiliter striatis, interstitiis planis.

Long. 5 lin., $\delta$ 우.

Allied to $A$. deplanatus (White), from which it is at once distinguished by the tawny-yellow colour of antennæ, palpi, and legs. From other allied species it is distinguishable by the form of the thorax, which is not at all strongly narrowed behind, but gradually and slightly, the anterior part of the sides being also gently rounded: 
the shallow lateral groove begins as a broad depression, with the basal fovea, and extends towards the front, gradually becoming narrower and fainter. The elytra are nearly plane, smooth, and opaque, regularly elongate-oval, with sharp lateral edges: the interstices are quite flat, and the three punctures of the 3rd very well marked. The labrum is broadly and distinctly emarginated. The mesosternal epimera are short and broad as in the sub-genus Platynus.

Otago.

(To be continued).

NOTES REGARDING SOME RARE PAPILIONES.

BY D. GREIG RUTHERFORD, F.L.S.

2. Papilio Homerus, Fabr.

Originally described by Fabricius (Ent. Syst., iii, 1, 1793) from a drawing made by Jones, taken, according to Donovan (Nat. Rep., i) from a specimen in the possession of Drury; and in 1801 more fully described, and, for the first time, figured, by Esper in his "Ausländische Schmetterlinge," this splendid Papilio has, until within the last few years, been rarely met with in European collections. In England it has, I believe, been confined to those of the British Museum, the Hope Museum at Oxford, and that of the late Mr. W. C. Hewitson. This is the more remarkable, since its habitat (Jamaica) has long been well known-has been frequently visited by naturalists, and in all directions traversed by English travellers who, we may readily conclude, would spare no pains to secure such a gorgeous and conspicuous insect, if it came in their way.

$P$. Homerus has already been so well and so fully described by Godart in the "Encyclopédie Méthodique," and by Boisduval in the first volume of his "Species Générales," that it is unnecessary for me to do more than supplement their work. This I am fortunately enabled to do from a comparison of a number of fine specimens recently received by my friend Mr. F. J. Horniman from Jamaica, the only region in which, so far as I can learn, this species has hitherto been found. My comparison results in the following addition to the descriptions referred to :

Upper surface of both pairs of wings varying from dark brown to deep black: transverse bands varying from a bright lemon colour to rich yellow. Apical spots usually five, sometimes all but the upper two suppressed. Lunules on hind wings generally five, various shades of yellow, orange, or bright red, often very faint, and in some ex- 


\section{$2 \mathrm{BHL}$ Biodiversity Heritage Library}

Bates, Henry Walter. 1878. "New species of geodephagous Coleoptera from New Zealand." The Entomologist's monthly magazine 15, 22-28.

https://doi.org/10.5962/bhl.part.22015.

View This Item Online: https://www.biodiversitylibrary.org/item/36482

DOI: https://doi.org/10.5962/bhl.part.22015

Permalink: https://www.biodiversitylibrary.org/partpdf/22015

\section{Holding Institution}

Smithsonian Libraries

\section{Sponsored by}

Smithsonian

\section{Copyright \& Reuse}

Copyright Status: NOT_IN_COPYRIGHT

This document was created from content at the Biodiversity Heritage Library, the world's largest open access digital library for biodiversity literature and archives. Visit BHL at https://www.biodiversitylibrary.org. 